\title{
Cultura Cultura
}

Revista de Historia Teeria das deleas $\quad$ Revista de História e Teoria das Ideias

Vol. 25 | 2008

Varia

\section{Emancipacionismo e abolicionismo}

Tensões de um debate no Brasil escravista

Emancipacionism and Abolicionism - a debate in Brasil of slavery

José D'Assunção Barros

\section{OpenEdition}

Journals

Édition électronique

URL : http://journals.openedition.org/cultura/695

DOI : $10.4000 /$ cultura.695

ISSN : 2183-2021

Éditeur

Centro de História da Cultura

Édition imprimée

Date de publication : 1 juin 2008

Pagination : 199-231

ISSN : 0870-4546

Référence électronique

José D'Assunção Barros, «Emancipacionismo e abolicionismo », Cultura [Online], Vol. 25 | 2008, posto online no dia 01 outubro 2013, consultado a 19 abril 2019. URL : http://journals.openedition.org/ cultura/695; DOI : 10.4000/cultura.695 


\section{Emancipacionismo e abolicionismo \\ - Tensões de um debate no Brasil escravista}

José D’Assunção Barros*

\section{A luta de representações em torno do fim da Escravatura}

Durante o período escravocrata no Brasil, para além do confronto entre as posições escravista e anti-escravista, é notório que se delinearam modos distintos de avaliar o problema de uma possível abolição da escravatura, por parte daqueles que a desejavam. Deveria a escravatura ser abolida gradualmente, de modo a não colapsar uma economia e uma sociedade francamente apoiadas na exploração do trabalho escravo? Deveria a abolição ocorrer de uma só vez, definitivamente? E, se fosse esta a opção, deveria estar prevista algum tipo de indenização aos antigos senhores de escravos que subitamente perderiam um patrimônio (a escravaria) que implicava na sua própria riqueza? Mais ainda, deveriam ser asseguradas aos libertos a possibilidade de realizar sua cidadania plena em um mundo que os receberia em desigualdade de condições? A Abolição da Escravidão deveria vir acompanhada de uma correspondente Reforma Agrária e outras medidas como uma reforma educacional - de modo a oferecer efetivamente aos antigos escravos uma possibilidade real de sobreviver no mundo do trabalho livre?

Todas estas perguntas, já mesmo ao serem formuladas, revelam uma certa diversidade de posições no mundo das idéias anti-escravistas que foi coetâneo ao contexto das décadas que precederam a abolição da escravatura no Brasil. Esta luta de representações em torno das possibilidades de trânsito para um mundo sem escravidão - expressa através de um confronto pleno de tensões realizadas ao nível discursivo - constituiu na história das idéias abolicionistas o contraponto de uma intensa luta social e política que não deixou de ter seus lances violentos, ao lado dos lances parlamentaristas. O nosso objetivo será examinar este debate, confrontando algumas das várias posições possíveis.

Para compreendermos mais claramente as idéias que estavam em jogo em umas e outras destas posições, partiremos da proposição de que existiam duas maneiras de enxergar a escravidão, desde a sua instituição no Brasil. A princípio, a escravidão pode ser vista como um sistema de Desigualdades. Mas também não é menos verdade que,

\footnotetext{
* Universidade Severino Sombra de Vassouras.
} 
em um mundo senhorial que desejava conciliar o cristianismo e o escravismo, para além de fixar o escravo em posições sociais bem definidas, a escravidão também foi vista como um sistema de Diferenças. A própria escolha do negro capturado ou comprado na África para objeto da escravidão representava essa pedra de toque no escravismo colonial. Racializada, a Escravidão poderia ser repensada como um sistema que absorvia uma "humanidade inferior". O Escravo Negro, na verdade um Desigual, podia ser visto como um Diferente. Ao invés de encarar o cativo africano trazido ao Brasil como alguém que está escravo (uma Desigualdade) a ideologia escravista procurava enxergar o africano de pele negra como alguém que é escravo (uma Diferença).

A ação dos abolicionistas à altura das décadas que precedem a Abolição se daria precisamente em torno do reconhecimento de que na sociedade escravocrata brasileira o "negro-escravo" era já tratado como diferença, e que era importante reconduzir esta discussão ao plano das desigualdades. A ação social pode com muito mais facilidade impor transformações no eixo circunstancial das desigualdades do que na coordenada de contrariedades das diferenças ${ }^{1}$. Considerar o escravo como um ser humano inferiorizado (alguém que sofre uma desigualdade) é fundamentalmente distinto de considerar o escravo como um ser humano inferior (alguém que está preso a uma diferença).

De modo geral, é possível perceber através dos textos e discursos dos abolicionistas que estes tiveram uma intuição bastante clara de que o seu discurso deveria simultaneamente enfatizar a 'desigualdade' da escravidão e rejeitar a imagem do escravo como 'diferença', e é este aspecto que estará nos interessando mais diretamente neste momento. Por outro lado, para entendermos os meandros das discussões que se dão em torno do fim ou da manutenção da escravatura, será preciso antes de mais nada vislumbrar as suas correntes internas..

Começaremos por contrastar as propostas meramente 'emancipacionistas' - as que, embora advogando o fim da escravatura, buscavam alcançá-lo através de medidas graduais e paliativas - e as propostas 'abolicionistas' propriamente ditas, estas ancoradas na idéia de supressão imediata e radical da escravidão. De igual maneira, para levar adiante a compreensão dos matizes internos ao abolicionismo, é possível identificar um pensamento abolicionista mais conservador, que sustentava medidas de indenização aos senhores de escravos pelas perdas que estes pudessem vir a ter com o fim da escravidão, e um pensamento abolicionista mais radical, não apenas nos métodos preconizados para alcançar

\footnotetext{
Ver, a este respeito, a discussão sobre a distinção entre os conceitos de Desigualdade e Diferença desenvolvida em BARROS, José, "Igualdade, desigualdade e diferença - Rediscutindo três noções". Análise Social (Revista do Instituto de Ciências Sociais da Universidade de Lisboa), n. 175, volume 11, verão de 2005, pp. 345-366.
} 
o fim da escravidão como na própria recusa em fazer concessões aos senhores de escravos. Abolicionistas (radicais ou conservadores), emancipacionistas, e, naturalmente, os próprios 'escravistas' que sustentavam ferrenhamente a manutenção do regime escravocrata: todos conviveram nestas duas últimas décadas do sistema escravista, sobretudo a partir de meados dos anos 1870.

\section{O Emancipacionismo: recusa em discutir como diferença a desigualdade escrava}

Os matizes que se desenvolviam em torno do pensamento sobre a questão escrava, e particularmente a diferenciação que deve ser feita entre "emancipacionismo" e "abolicionismo", transparecem claramente na literatura da época e nas posições que se expressam através dos discursos políticos com suas conseqüentes ações legais. Joaquim Nabuco, um dos mais sofisticados e conscientes entre os escritores e políticos abolicionistas do final do Império, assim se coloca em sua obra O Abolicionismo (1883) diante da necessidade de compreender a distinção entre ações emancipacionistas e propostas abolicionistas propriamente ditas:

"A política dos nossos homens de Estado foi toda, até hoje, inspirada pelo desejo de fazer a escravidão dissolver-se insensivelmente no país. / O Abolicionismo é um protesto contra esta triste perspectiva, contra o expediente de entregar à morte a solução de um problema que não é só de justiça e consciência moral, mas também de previdência política."2

Há contudo uma história anterior que precede estes anos mais efervescentes de debate anti-escravagista. Um texto pioneiro deve ser atribuído a José Bonifácio de Andrada e Silva, monarquista constitucionalista que se destacou nos primeiros anos do Império ${ }^{3}$. Teremos aqui um exemplo primordial do pensamento 'emancipacionista', já que a proposta era neste caso a de supressão gradual da escravidão. Neste Projeto, ao qual nos referiremos como Representação sobre a Escravatura (1988), o estadista enfatiza de imediato, embora utilizando suas próprias palavras e modos de expressão, a cruel combi-

2 NABUCO, Joaquim. O Abolicionismo in SANTIAGO, Silviano (org.) Intérpretes do Brasil. Rio de Janeiro: Nova Aguilar, 2002. pp. 23-167. [original: Londres: 1883], p. 25.

3 O Projeto para a questão escravocrata de José Bonifácio, então deputado por São Paulo, foi apresentado à Assembléia Geral Constituinte e Legislativa do Império em 1823. Apresenta-se como uma extensa argumentação em defesa do fim da Escravidão, na qual o deputado paulista do Império sugere desde prazos para o fim do comércio de escravos como também mecanismos direcionados para a abolição gradual da escravidão, refletindo inclusive sobre a reorganização da vida jurídica, econômico-social, cultural e familiar dos escravos libertos. 
nação de 'diferença escrava' e 'desigualdade escrava', ressaltando sintomaticamente que os africanos e afro-descendentes escravizados de sua época "não tem pátria," mas que "podem a vir a ser nossos irmãos e nossos compatriotas".

É preciso recuperar para os negros submetidos à escravidão, é nestes termos que José Bonifácio se expressa, "a dignidade de homens e cidadãos"4, pelo que a questão se vê desde já colocada em termos de 'ausência de cidadania' (uma desigualdade, portanto, e não uma diferença). Em outro ponto do discurso de José Bonifácio, aliás, ressalta o fato de que a transformação dos escravos em cidadãos permitiria precisamente modificar o seu status de "inimigos internos" para aliados, perfeitamente inseridos no projeto nacional. Trata-se então de deixar de enxergar o escravo como o outro, como a diferença submetida à escravidão e que se coloca como o inimigo ou opositor interno, e conceder-lhe um lugar na sociedade civil e na civilização. Admitido o antigo escravo como cidadão perfeitamente integrado à terra, agora já purgado definitivamente de sua diferença escrava, fica de resto implícito que o trabalho a partir daí será o de atenuar desigualdades. Passamos portanto de um eixo a outro, das diferenças às desigualdades, é disto essencialmente que se trata.

Com relação à questão negra, deve-se ressaltar que José Bonifácio não atribui ao africano, como de resto era tão comum entre os políticos e escritores da época, o pretenso ambiente de depravação que habitualmente se descreve como conseqüência do regime de trabalho escravista. Toda a ênfase de depreciação deve recair neste caso, segundo a ótica de Bonifácio, não sobre a figura racial do africano, e sim sobre a figura social do escravo, ou, melhor dizendo, sobre a noção desigualadora de escravo:

"Tudo se compensa nesta vida. Nós tyrannizamos os escravos e os reduzimos a brutos animaes; eles nos innoculam toda a sua immoralidade e todos os seus vícios."

A Escravidão, desta maneira, macula e deteriora tanto aos senhores como aos escravos, como em um rio de dupla corrente que não apresenta nem propriamente um vilão e nem uma única vítima. Na verdade, tal parece se depreender da argumentação de José Bonifácio, o rio escravocrata é o vilão, e as vítimas são simultaneamente os senhores e escravos, as duas posições sociais que constituem o sistema. Não há um problema étnico na base desta degradação que seria o escravismo, de acordo com o discurso sustentado pelo Patriarca da Independência, mas sim um problema social de base, este sim um ver-

4 ANDRADA E SILVA, José Bonifácio de. "Representação à Assembléia Geral Constituinte e Legislativa do Império do Brasil sobre a Escravatura" In MACIEL COSTA, João Severiano Maciel da et alii. Memórias Sobre a Escravidão. Rio de Janeiro / Brasília: Arquivo Nacional / Fundação Petrônio Portella / Ministério da Justiça, 1988, p. 68. 
dadeiro obstáculo para as possibilidades de efetivo progresso e de assegurar o pleno desenvolvimento civilizacional no Brasil. É interessante notar que a idéia de que o que se deve atacar não é propriamente a mera sujeição do escravo, mas sim a dicotomia "senhor / escravo", irá reaparecer décadas depois no discurso mais propriamente abolicionista de um Joaquim Nabuco:

“Por outro lado, a emancipação não significa tão somente o termo da injustiça de que o escravo é mártir, mas também a eliminação simultânea de dois tipos contrários, e no fundo os mesmos: o escravo e o senhor." ${ }^{5}$

Recolocar a questão nestes termos, seja no emancipacionismo de José Bonifácio ou no abolicionismo de Joaquim Nabuco, é sustentar que o que deve ser suprimido não é um pólo - o escravo - mas sim a própria dicotomia polarizada entre 'senhores' e 'escravos': um eixo de desigualdades inteiro, portanto. Este é por sinal um dos sintomas de que aqui a questão escrava mostra-se colocada em termos de desigualdades, e não de diferenças. A eliminação de um termo essencial pode ser tentada quando consideramos o âmbito das diferenças (embora saiba-se lá a que custos), mas a eliminação de um par circunstancial só pode se produzir no âmbito das desigualdades. Para eliminar a 'diferença escrava', à maneira como alguns escravistas a concebiam, seria preciso libertar os africanos e depois deportá-los para a África (este projeto, foi de fato proposto em 1822 nos EUA pela American Colonization Society, que se dispôs a fundar no continente africano um país - a Libéria - constituído por libertos do escravismo americano). Mas para suprimir a 'desigualdade escrava' seria preciso eliminar um eixo inteiro: quando se suprime o senhor, suprime-se o escravo, e vice-versa ${ }^{6}$. No eixo das desigualdades, a supressão de um pólo implica imediatamente na desintegração do outro - este é o nó da questão.

Retornando à questão emancipacionista, a proposta de José Bonifácio para esta escravatura que corrompia a sociedade como um todo, como se disse, era a da "libertação gradual" - não a libertação de toda a massa de escravos de uma única vez, pois isto poderia trazer problemas econômicos e sociais graves, mas sim a libertação por camadas escravas, passo a passo. Tratava-se de evitar a morte súbita da Escravidão, que viria com a ado-

5 NABUCO, 2002, p. 32.

6 Todo o problema com a Lei do Ventre Livre (1871), este ponto culminante das propostas emancipacionistas, era precisamente o fato de que a mera transformação dos 'escravos por nascer' em "ingênuos", uma nova categoria social que ali se criara, simplesmente deixava intacta a classe dos senhores, e conseqüentemente os ingênuos continuaram a ser dependentes dos mesmos senhores que já eram os donos de seus pais. 
ção da Abolição instantânea, e de substituí-la pela morte lenta, assimilável à sociedade escravocrata. Por outro lado, o fator gradualista da proposta também apresenta um outro sentido, bem diverso, não mais relativo à massa escrava enquanto objeto, mas sim ao indivíduo escravo enquanto sujeito. Postula-se que não se pode passar de um pólo a outro, de escravo a livre, como quem atravessa uma via pública. Era preciso uma preparação, esta envolvendo simultaneamente a massa escrava, cada indivíduo escravo a ser libertado, a elite senhorial, e a economia do país como um todo.

De qualquer maneira, depois de uma arguta análise da conjuntura mais imediata de seu tempo, na continuidade do texto de José Bonifácio parecem ser evocadas claramente as desigualdades que ainda estariam por vir, já ao nível liberto, caso o processo de abolição não fosse adequadamente conduzido e não fossem proporcionadas as devidas oportunidades de sobrevivência e trabalho aos ex-escravos a serem absorvidos pela sociedade já como cidadãos livres:

"Torno a dizer que não desejo ver abolida de repente a escravidão; tal acontecimento traria consigo grandes males. Para emancipar escravos sem prejuízo da sociedade, cumpre fazê-los primeiramente dignos da liberdade: cumpre que sejamos forçados pela razão e pela lei a convertê-los gradualmente de vis escravos em homens livres e ativos." ${ }^{77}$

Para a questão que nos interessa, há neste discurso a referência a uma 'diferença' (os "vis escravos") que deve ser convertida formalmente em 'desigualdade' - deslocamento a vir amparado no reconhecimento de que nos meios escravos existem apenas seres humanos submetidos a condições desumanas e desigualadoras - para que a partir daí gradualmente os próprios escravos pudessem ser convertidos em "homens livres e ativos". "Gradualmente" (grifo nosso) marca exatamente a evocação ao eixo de contradições, onde é possível haver uma reversibilidade e um deslocamento espectral do âmbito dos mais desiguais em direção ao mundo plenamente realizado dos iguais, aqui idealizados pelo duplo atributo de "homens livres e ativos". Trata-se, enfim, de trazer a questão do plano de contrariedades das 'diferenças escravas' para o plano de contraditoriedades das 'desigualdades escravas', pois é somente neste plano que pode ser estabelecida efetivamente uma ação social com vista a amenizar, diminuir ou mesmo eliminar as injustiças sociais. Libertar sem proporcionar condições econômicas e acesso ao trabalho para os novos homens livres, parece estar implícito no texto, é sujeitar a sociedade a "grandes males", à possibilidade da marginalização, ao crime, à miséria, à ociosidade. 
Da mesma forma que examina a necessidade de uma abolição gradual, socialmente conduzida de modo a evitar desigualdades e distúrbios posteriores, José Bonifácio defende a idéia de que a própria instituição da Escravidão havia se constituído originalmente em um obstáculo em potencial ao progresso futuro da nação brasileira que agora se tornava independente. O que estaria contaminando a sociedade brasileira de seu tempo, conforme se pode ver no discurso de José Bonifácio, não era a 'diferença negra', mas a 'desigualdade escrava'. A facilidade de pôr um outro indivíduo a trabalhar gratuitamente para si, segundo o deputado do Império, contribuía para lançar a classe senhorial no ócio, na estagnação, na imobilidade:

“O luxo e a corrupção nasceram entre nós antes da civilização e da indústria. E qual será a causa principal de um fenômeno tão espantoso? A Escravidão, senhores, a escravidão, porque o homem que conta com os jornais de seus escravos vive na indolência, e a indolência traz todos os vícios após si." ${ }^{8}$

O texto pioneiro de José Bonifácio em favor da extinção da escravatura - contemporâneo à tradução para o português do opúsculo "Os Gemidos dos Africanos" de Thomas Clarkson (1823) - é apenas um exemplo do deslocamento que estava por se operar entre a coordenada das diferenças e a diagonal das desigualdades. Posteriormente viriam outros, já no âmbito dos discursos abolicionistas. Mas desde já cumpre observar, ainda com base em uma última transcrição deste texto pioneiro com relação ao tratamento da questão escrava, que o gesto fundador do projeto anti-escravista está em reconhecer isso que poderemos chamar de um 'pecado original da instituição de uma diferença escrava'. Já nestes inícios do Império, José Bonifácio assim se expressava, preludiando o debate abolicionista que estaria por vir em décadas posteriores:

“Com efeito, senhores, nação nenhuma, talvez, pecou mais contra a humanidade do que a portuguesa, de que fazíamos outrora parte. Andou sempre devastando não só as terras de África e Ásia, como disse Camões, mas igualmente a de nosso país. Foram os portugueses os primeiros que, desde os tempos do infante $\mathrm{D}$. Henrique, fizeram um ramo do comércio legal de prear homens livres, e vendê-los como escravos nos mercados europeus e americanos. Ainda hoje perto de 40000 criaturas humanas são arrancadas da África, privadas de seus lares, de seus pais, filhos e irmãos, transportados às nossas regiões, sem a menor esperança de respirarem outra vez os pátrios ares, e destinadas a trabalhar toda vida debaixo do açoite cruel de seus senhores, elas, seus filhos, e os filhos de seus filhos para todo o sempre!"9

8 ANDRADA E SILVA, 1998, p. 64.

9 ANDRADA E SILVA, 1988, p. 63. 
É preciso examinar a questão da instituição da Escravidão e da conseqüente necessidade da libertação de escravos, tal parece nos colocar o texto de José Bonifácio, não como uma questão de âmbitos inter-individuais (conceder alforrias, por exemplo), mas sim como um problema de dimensões coletivas (de assumir a extinção da escravatura conscientemente como um "projeto social"). Este abismo essencial entre duas posições radicalmente distintas se coloca claramente quando examinamos as ações inter-individuais encaminhadas pelos senhores mais generosos através da alforria (por vezes camuflando interesses mesquinhos, já o vimos) e as ações sociais efetivas, como aquelas que logo estariam sendo propostas pelas idéias abolicionistas. Neste último caso, a libertação não pode vir como um prêmio, como uma concessão - como uma "alforria". Precisa vir, isso sim, como o restabelecimento de um equilíbrio e justiça social que haviam sido rompidos com o próprio gesto escravizador original: um gesto que não pode mais ser atribuído a indivíduos - estes mercadores que instituíram o tráfico negreiro e que são referidos por José Bonifácio como "vendedores de carne humana"10. É preciso reputar este gesto escravizador original, agora, aos portugueses como um todo (e neste ponto, aliás, José Bonifácio cria uma sutil diferença entre os brasileiros e seus antigos colonizadores, ao referir-se à nação portuguesa como aquela "de que outrora fazíamos parte") $)^{11}$. É preciso enfim conceber a Escravidão ou qualquer outra desigualdade social como o aviltamento imposto por uma sociedade contra uma outra, ou contra parte dela mesmo, e não como ações que se dão entre indivíduos. Esta seria inclusive a chave por trás do discurso abolicionista, a única chave capaz de conduzir a questão escravocrata, hipocritamente ou não, nos limites do único plano nocional que permite em tese as ações sociais: o plano das desigualdades sociais ${ }^{12}$.

10 Aqui José Bonifácio se pergunta, com bastante eloqüência: "que justiça tem um homem para roubar a liberdade de outro homem, e o que é pior, dos filhos deste homem, e dos filhos destes filhos?" (ANDRADE E SILVA, 1998).

11 A estratégia discursiva de criar uma diferença entre o antigo colonizador português e o brasileiro, aliás, central neste texto de José Bonifácio, é reforçada por uma outra passagem particularmente interessante, onde a própria escravidão é apontada como estratégia dos antigos dominadores portugueses para minar as possibilidades de uma futura nação brasileira em formação: "Se o antigo despotismo foi insensível a tudo isso, assim lhe convinha a ser por utilidade própria: queria que fôssemos um povo mesclado e heterogêneo, sem nacionalidade e sem irmandade, para melhor nos escravizar" (ANDRADA E SILVA, 1988, p. 61).

12 É aliás oportuno ressalvar que, ao mesmo tempo em que José Bonifácio conduz o seu discurso favorável à abolição em termos de humanitarismo, dá-lhe um amplo suporte em termos de eficiência empresarial. Da mesma forma, como que a piscar um olho para cooptar os senhores de terra ainda indecisos, faz questão de mostrar-lhes que eles não precisam temer modificações sociais muito profundas que afetem as hierarquias econômicas até então existentes e muito menos o sistema de propriedades 
A Representação contra a Escravidão de José Bonifácio foi por certo um marco importante no pensamento anti-escravagista, embora não tenha resultado em medidas concretas. Não foi por outro lado o único texto emancipacionista - isto é, com a proposta clara de uma extinção gradual da Escravidão no Brasil - uma vez que outros análogos surgiram nestas mesmas cinco décadas situadas entre os anos que precedem a Independência e os anos abolicionistas que principiam na década de 1870. De todo modo, as poucas contribuições emancipacionistas transformadas em texto acham-se de fato espalhadas ao longo de cinco décadas de escravatura e podem ser facilmente contadas nos dedos, o que contrasta intensamente com a profusão de textos abolicionistas dos anos 1870 não apenas no que se refere ao seu conteúdo, como também na sua quantidade e na concentração muito maior de textos em um curto período de tempo (menos de duas décadas).

Para o período que neste momento consideramos, é preciso registrar que, antes mesmo de José Bonifácio defender a sua Representação contra a Escravidão, já tínhamos, da lavra de João Severiano Maciel da Costa, um texto cujo longo título já nos diz muita coisa: Memória sobre a necessidade de abolir a introdução de escravos africanos no Brasil, sobre o modo e as condições com que esta abolição se deve fazer e sobre os meios de remediar a falta de braços que ela pode ocasionar (1821)13. A obra - em alguns pontos ancorada em idéias que já eram amplamente difundidas nos meios abolicionistas ingleses, pode ser inserida nesta onda bastante diluída de propostas emancipacionistas que atravessa as cinco décadas que precedem os anos 1870. Mas, por outro lado, A Memória de Maciel da Costa mostra-se ainda um texto bastante ambíguo. Ao mesmo tempo em que se opunha explicitamente ao tráfico e à Escravidão no Brasil, reconhecia o autor que esta ainda deveria seguir algum tempo em vista dos interesses públicos, e até mesmo a justificava em algumas passagens mais específicas. Assim, por um lado Maciel da Costa acompanhava de perto o discurso inglês da época e as posições ilustradas ao registrar que a compra e venda de escravos era uma ofensa à humanidade, já que "os homens nascem livres" (a Escravidão, portanto, é de acordo com esta observação um assunto de Desigualdade, e não de Diferença). Mas ao mesmo tempo, em outras passagens que parecem anular esta postura inicial, terminava por recair no velho discurso de que transportar os escravos da

vigentes. Os escravos libertos, assevera, não constituirão ameaça à ordem social já estabelecida, pois para "ganharem a vida aforarão pequenas porções de terras descobertas ou taperas, que nada valem" (ANDRADA E SILVA, 1998, p. 62).

13 João Severiano Maciel da Costa (1769-1833) - o Marquês de Queluz - ocupou vários cargos importantes no Império, como o de Ministro do Império, Ministro da Fazenda, Conselheiro de Estado, presidente da província da Bahia, e Senador do Império do Brasil - função que desempenhou desde 1826 até o ano de sua morte em 1833. 
África para o Brasil não era, no fim das contas, assim tão ruim, em vista dos benefícios que a mudança dos africanos para um ambiente mais civilizado poderia lhes proporcionar ${ }^{14}$ :

"Que é muito, pois, que os bárbaros ferozes africanos sejam transportados dos seus areais ardentes para o belo clima do Brasil, e aí empregados no suave trabalho da agricultura?"

Portanto, embora partindo de um discurso e de uma postura inicial contra a Desigualdade Escrava, Maciel da Costa acaba, em passagens como esta, recaindo na concepção da Diferença Negra justificadora de uma Diferença Escrava ${ }^{15}$. Ao se referir às nações africanas envolvidas com a ponta africana do tráfico, também deixa escapar a opinião de que "nações [negras] houve que instituíram a escravidão, incorporando-a à sua organização política", sem querer se dar conta de que basicamente as nações africanas que se constituíram para o tráfico, já no período moderno, assim o fizeram sob a influência da instalação de um poderoso tráfico atlântico que distribuía lucros para todas as suas pontas. Isto é, diferentemente da escravidão localizada que já existia na África ou do comércio-escravo de amplitude mais moderada que de longa data vigorava com o circuito islâmico, os reinos africanos que no período moderno incorporaram a Escravidão à sua estrutura política assim o fizeram por influência dos europeus, e não por um movimento natural, tal como Maciel da Costa parece sustentar. Ambigüidades à parte, em todo o caso o autor posiciona-se favoravelmente ao fim gradual da Escravidão no Brasil, o que o aproxima das idéias emancipacionistas.

É já uma obra mais marcadamente emancipacionista a Memória sobre a Escravatura e projeto de colonização dos europeus e pretos da África no Império do Brasil, escrita por José Eloy Pessoa da Silva (1826). Reaparece aqui a tônica da abolição gradual, com a proposta de que houvesse incentivos para uma colonização do Brasil que fosse partilhada por índios, europeus e africanos. Mais ainda, uma outra obra - a Memória analítica acerca do comércio de escravos e acerca dos males da escravidão doméstica (1837) - escrita 11 anos

14 MACIEL DA COSTA, João Severiano. "Memória sobre a necessidade de abolir a introdução de escravos africanos no Brasil, sobre o modo e condições com que esta abolição se deve fazer e sobre os meios de remediar a falta de braços que ela pode ocasionar (1821)" in MACIEL DA COSTA et alii. Memórias Sobre a Escravidão. Rio de Janeiro / Brasília: Arquivo Nacional / Fundação Petrônio Portella / Ministério da Justiça, 1988, pp. 9-61.

15 O argumento da "tutela benéfica" do senhor sobre o escravo também teria ampla difusão entre os defensores do escravismo. Em 1870, às vésperas da promulgação da Lei do Ventre Livre, Peixoto de Brito também sustentava este mesmo argumento, além de defender a idéia de que, em última instância, caso a abolição fosse necessária, esta não poderia ocorrer sem uma indenização correspondente aos senhores, sob o risco de ser instituída uma espécie de "lei do rouba da propriedade particular" (SILVA, José Eloy Pessoa da. "Memória sobre a escravatura e projeto de colonização dos europeus e pretos da África no Império do Brasil (1826)" in MACIEL DA COSTA, op. cit., p. 416). 
depois por Leopoldo César Burlamaque, denunciava no título algum avanço na discussão emancipacionista, já que se propunha a examinar, com vistas a corrigi-los, os efeitos da escravidão no futuro $^{16}$. Estes exemplos, embora relevantes, ainda são obviamente muito esparsos. Apesar destas poucas iniciativas de discutir o tema das possibilidades de extinção da escravatura, ainda seria preciso esperar um pouco mais para que se fizesse ouvir um discurso abolicionista mais consistente.

\section{O Abolicionismo: proposta de supressão imediata da desigualdade escrava}

A história do discurso anti-escravagista tem os seus ritmos próprios. Apesar dos significativos investimentos de José Bonifácio e de alguns poucos autores do Primeiro Reinado no questionamento emancipacionista do sistema escravocrata, não há como negar que a produção discursiva anti-escravagista desta época não pode ser comparada com a que tomaria forma algumas décadas mais tarde. De fato, pode-se mesmo perceber, entre o início do Primeiro Reinado e o período mais intenso de crítica abolicionista que se dá no final do Segundo Império, um certo vazio discursivo a ser considerado no que concerne a uma expressão mais incisiva e radical da questão anti-escravagista (não um vazio de lutas, veja-se bem). Rigorosamente falando, praticamente não há naquela primeira época grandes discussões sobre o fim do escravagismo que possam ombrear com aquelas que surgiriam nos anos 1870 - à parte, é claro, os já mencionados textos emancipacionistas de autores mais isolados e uma notável "fala do trono" pronunciada por Dom Pedro II em 1867, na qual o Imperador também se coloca a favor de um 'emancipacionismo' gradual, sugerindo que a questão fosse discutida pelos políticos do Império. Esta fala régia, aliás, mobilizaria nos quatro anos seguintes os debates que conduziriam à Lei do Ventre Livre promulgada em 1871, mas esta deve ser considerada como uma primeira grande medida 'emancipacionista" (e não 'abolicionista'), uma vez que com ela aponta-se não para a supressão imediata da escravatura, e sim para este deixar que a escravatura morra naturalmente, já que com a nova lei não nasceriam mais escravos e os já existentes terminariam por morrer um dia, extinguindo-se com isso a Escravidão.

${ }^{16}$ Outros textos podem ser citados, como o projeto proposto pela 'Sociedade contra o tráfico de Africanos e promotora da colonização da civilização dos indígenas' (1852). Este texto tem um título marcadamente emancipacionista: "O sistema de medidas adaptáveis à progressiva e total extinção do tráfico e da escravatura no Brasil", e algumas de suas propostas dirigem-se ao apoio do governo para a adoção do trabalho livre concomitante à "extinção progressiva da escravatura". Datado de 1845, existe ainda um texto de Veloso de Oliveira - que ocupava o cargo de desembargador da relação de Pernambuco - e que aponta na mesma direção (MACIEL DA COSTA, 1980, p. 408). 
Tanto o caráter gradualista do pensamento emancipacionista de todo o período anterior aos anos 1870, como também os vazios entre as suas maiores manifestações, são percebidos com clareza por Joaquim Nabuco, ele mesmo já um abolicionista no sentido stricto. Nabuco enxerga no período anterior apenas duas realizações concretas: a supressão do tráfico em 1850 (Lei Eusébio de Queiroz), e a libertação dos escravos por nascer através da Lei do Ventre Livre em 1871. Antes e entre estas duas medidas que na verdade não atacam diretamente o problema da escravidão, mas apenas restringem o seu campo de ação, Nabuco também identifica um relativo vazio discursivo ("uma calmaria profunda" ou um "período de cansaço", conforme as próprias palavras do escritor e político abolicionista):

“A primeira oposição nacional à Escravidão foi promovida tão somente contra o Tráfico. Pretendia-se suprimir a escravidão lentamente, proibindo a importação de novos escravos. À vista da espantosa mortalidade desta classe, dizia-se que a escravatura, uma vez extinto o viveiro inesgotável da África, iria sendo progressivamente diminuída pela morte, apesar dos nascimentos. / Acabada a importação de africanos [...] seguiu-se à deportação dos traficantes e à lei de 4 de setembro de 1850 uma calmaria profunda. Este período de cansaço, ou de satisfação pela obra realizada - em todo o caso de indiferença absoluta pela sorte da população escrava - durou até depois da Guerra do Paraguai, quando a Escravidão teve que dar e perder outra batalha. Essa segunda oposição que a Escravidão sofreu, como também a primeira, não foi um ataque ao acampamento inimigo para tirar-lhe os prisioneiros, mas uma limitação apenas do território sujeito às suas correrias e depredações. / Com efeito, no fim de uma crise política permanente, que durou de 1866 até 1871, foi promulgada a lei de 28 de setembro [a Lei do Ventre Livre], a qual respeitou o princípio de inviolabilidade do domínio do senhor sobre o escravo, e não ousou penetrar, como se fora um local sagrado, interdito ao próprio estado, nos ergástulos agrários." ${ }^{17}$

Joaquim Nabuco identifica com especial clareza esse vazio de ações efetivas no seio da elite política do Império no que concerne à questão escrava: apenas duas medidas, uma visivelmente produzida sob a pressão dos interesses internacionais (leia-se ingleses) e que redundou na Supressão do Tráfico Atlântico em $1850^{18}$; outra que culminaria com a rea-

17 NABUCO, 2002, p. 24.

${ }^{18}$ A Lei Eusébio de Queirós, versando sobre a proibição do tráfico, foi aprovada em setembro de 1850. É bastante explícita com relação à punição dos envolvidos no processo do tráfico de escravos: "[...] Artigo 3.: são autores do crime de importação, ou de tentativa dessa importação, o dono, o capitão ou mestre, o piloto e o contramestre da embarcação, e o sobrecarga. São cúmplices a equipagem, e os que coadjuvarem o desembarque de escravos no território brasileiro de que concorrerem para ocultar ao 
lização incompleta expressa pela Lei do Ventre Livre, criadora desta nova categoria social - os "ingênuos" - mas que na prática continuariam a ser escravos filhos de escravos, dadas as condições de dependência que seriam conservadas em relação aos antigos senhores. Contra este pano de fundo, não se interessa Nabuco em mencionar neste momento, seguem-se as insubordinações escravas aos níveis individual e coletivo, as fugas de escravos e formação de quilombos, os crimes escravos de que nos prestam conta os inúmeros processos hoje encontráveis nos arquivos, e também, porque não dizer, as negociações do dia a dia, as alforrias mais conquistadas do que recebidas, as ações de liberdade, os meandros da mestiçagem. Tudo isto se agita na sociedade real dos brancos, negros e mulatos, homens livres, escravos e libertos, senhores escravistas e homens pobres, sob a impressionante calmaria discursiva da política imperial.

Podemos nos perguntar pelas razões possíveis para este esvaziamento do discurso anti-escravagista que se dá entre a Representação contra a Escravidão de José Bonifácio e as décadas abolicionistas, embora assinalado aqui e ali por um ou outro texto emancipacionista. De saída, pode-se aventar que o relativo vazio discursivo em termos de discussões anti-escravagistas corresponde perfeitamente àquelas a que já nos referimos como décadas de Diferença Escrava, e não é difícil articulá-lo ao contexto e às circunstancias históricas que o envolvem.

Vimos atrás que, nas 4 ou 5 décadas que correspondem ao período que vai de meados de 1820 aos anos 1860, alguns fatores se combinam. O preço do escravo começa a crescer neste período, até atingir seu ápice nos anos 1860. Acompanhando este processo, há um recrudescimento das manumissões, pelo menos no que concerne às possibilidades do escravo comum comprar a sua própria alforria. A idéia da Escravidão como um estado que pode ser revertido, tem aqui um recuo significativo. Isto significa dizer, vimos atrás, que se passa de um período onde predominava a Desigualdade Escrava (entre fins do século XVIII e inícios do século XIX) para uma fase de predomínio da Diferença Escrava. As revoltas malês na Bahia, exemplarmente reprimidas - e particularmente a de 1835 - são sintomas de um tempo em que o horizonte das conquistas individuais da liberdade através da alforria recua para segundo plano em relação ao período anterior, e os caminhos coletivos de libertação começam a se tornar mais expressivos. Temos também as pressões internacionais contra o tráfico atlântico, que haviam cunduzido à instituição em 1831 a uma primeira lei anti-tráfico - a Lei Feijó, uma "lei para inglês ver" que praticamente permaneceu letra morta - e posteriormente ao já mencionado fechamento do tráfico em 1850, o que

conhecimento da autoridade, ou para os subtrair à apreensão no mar, ou em ato de desembarque sendo perseguida." 
por um outro lado estimula depois desta data não apenas o contrabando como também o 'tráfico interno', com o deslocamento de escravos do norte para o sul (das zonas de açúcar, por exemplo, para as áreas do café, estas em plena ascensão) ${ }^{19}$. O tráfico interno, além disto, dá-se sob o signo de uma concentração da propriedade escrava, pois com o encarecimento do preço escravo os pequenos produtores tendem a buscar na venda de seus escravos para o tráfico interno uma solução com vistas a tentar sair de eventuais crises que, destarte, não deixam de favorecer "um recrudescimento do número de brancos empobrecidos, nas diversas situações rurais, locais e regionais"20.

Em oposição às quatro décadas de vazio discursivo que quase silenciam a respeito das possibilidades de reenquadrar o escravismo sob a ótica da desigualdade - já que os textos emancipacionistas neste largo período são bastante esparsos - os anos 1870 serão realmente efervescentes. As décadas de Diferença Escrava haviam sido conduzidas a seus limites, e se, para os interesses econômicos internacionais bastara, durante este período, que o tráfico atlântico fosse reprimido, agora todas as pressões já apontam para que seja desfeito o último reduto escravista das Américas. Na Rússia, a servidão fora abolida em 1861; nos Estados Unidos o Sul Escravista fora vencido (1865); e no âmbito europeu os interesses ingleses cada vez mais se fecham na idéia de que a página do escravismo colonial deveria ser virada definitivamente ${ }^{21}$. A sobrevivência da escravidão americana nos estados do sul, aliás, sempre constituíra um dos mais fortes argumentos dos defensores do escravismo no Brasil, de modo que subitamente o Império Brasileiro ficava praticamente sozinho como o último país escravista das Américas .

Ao nível interno da Economia, começam a surgir de uma para esta outra época os interesses industriais e os de outros setores da economia que não estão interessados na pre-

19 O fenômeno é adequadamente descrito por João Fragoso: "A rentabilidade da economia do Sudeste permitiu que os cafeicultores, entre outros senhores do Centro-Sul, suplantassem os senhores de engenho nordestinos no que diz respeito à posse de escravos. Um dos resultados deste processo fora a exportação de cativos do Nordeste para o Sul" (FRAGOSO, João. "O Império Escravista e a República dos Plantadores" in LINHARES, Maria Yedda (org.) História Geral do Brasil. Rio de Janeiro: Campus, 2000. p. 168).

${ }^{20}$ CASTRO, Hebe Maria Mattos. Das cores do silêncio. Os Significados da Liberdade no Sudeste Escravista - Brasil Século XIX. Rio de Janeiro: Arquivo Nacional, 1995, p. 104. Tal como assinala João Fragoso, "nos últimos anos de cativeiro, observou-se uma tendência à concentração de terras e homens em poucas mãos" $(2000,161)$.

${ }^{21}$ Sintoma da intolerância cada vez maior da Inglaterra diante das últimas sobrevivências escravistas foi o "Caso Christie", quando em torno da passagem para o ano de 1863 uma força naval inglesa realizou um breve bloqueio de seis dias no porto do Rio de Janeiro com vistas a reprimir o tráfico clandestino, resultando na apreensão de navios fora do porto e na eclosão de uma crise diplomática entre Brasil e Inglaterra que durou 2 anos. Ver CONRAD, Robert. Os últimos anos da escravatura no Brasil - 1850-1888. Rio de Janeiro: Civilização Brasileira, 1975, p. 89. 
servação do sistema escravista. Por fim, para assegurar uma nova modalidade de mão-de-obra para a lavoura, o Estado Imperial já desde os anos 1860 começara a incentivar a imigração. Nos anos 1870, os efeitos deste influxo de mão-de-obra já se fazem notar: o preço do escravo já não subiria, e a lavoura não tardaria a contar com um outro tipo de mão-de-obra22.

Enquanto isto, a este bloco de fatores econômicos que, na perspectiva de alguns setores econômico-sociais, vão redesenhando a instituição escravocrata como um modelo produtivo cada vez mais anacrônico, já vinham se contrapondo transformações no próprio seio da população escrava no que concerne a suas formas de sociabilidade. Em um mundo onde já não seria possível a migração forçada de africanos, alguns dentre os próprios senhores de escravos já estimulavam, com vistas a favorecer condições em que a natalidade finalmente superasse a mortalidade da escravaria, a formação de uma família escrava mais consistente. Diante do reconhecimento de que havia uma vida social e familiar para além do seu extenuante trabalho escravo, a dimensão humana do escravo negro ia sendo trazida, contra ou com a consciência senhorial, para primeiro plano. A 'humanização do escravo', naturalmente, favorece tão intensamente a leitura da escravidão como 'desigualdade social' como, no pólo oposto, a 'coisificação do negro' favorece a concepção da Diferença Escrava.

Mostram-se como sintomas muito claros da crescente humanização do escravo no imaginário das elites o lugar que, ao negro escravo, a própria literatura começa a dedicar. São por demais evidentes as contribuições poéticas trazidas por Castro Alves em seu livro Os Escravos e com suas duas obras-primas intituladas Vozes da África e O Navio Negreiro, esta última declamada pela primeira vez em 1868 e ambas obrigando o leitor a contemplar simultaneamente a desumanidade da idéia de uma Diferença Escrava e as injustiças que, sob ela, desenhavam-se como Desigualdade Escrava. De igual maneira, a figura humanizada do negro também começa a despontar na literatura em prosa - desde um discreto marco inicial com o romance $O$ Comendador de Pinheiro Machado (1856) até chegar a obras primas como O Mulato de Aluísio Azevedo (1881) . Com isto, o negro passava a receber um lugar destacado nos enredos literários, o que se intensifica a partir das décadas abolicionistas ${ }^{23}$.

22 Por outro lado, seria preciso esperar para 1884 as primeiras medidas mais concretas voltadas para uma "imigração subsidiada", com o que já se antecipa a necessidade de substituir a mão-de-obra escrava na lavoura.

${ }^{23}$ Naturalmente que a emergência do negro na literatura brasileira do Segundo Império presta-se, então, aos mais diversos estereótipos, e não apenas àqueles que interessam ao projeto abolicionista. Assim, às vésperas da abolição, o romance $A$ Carne de Júlio Ribeiro (1888), mostra-nos uma situação "onde, segundo o narrador, a liberação dos instintos de Lenita, a branca personagem central, se deve à pro- 
A humanização do escravo, por uma outra via bem distinta, também se afirmava sempre que os escravos e ex-escravos lutavam por isto. As lutas políticas dos próprios escravos, dos ex-escravos, dos mulatos filhos de escravos, também contribuem - e na verdade ainda mais extraordinariamente - para que se afirme a humanidade do escravo. Insurreições coletivas, fugas de escravos para os quilombos, cada vez mais em grupos maiores, e sobretudo a formação de organizações de escravos fugidos e ex-escravos já articulados às metas abolicionistas... tudo isto começava a fazer com que, nas duas últimas décadas escravocratas, gritasse por todos os lados a humanização escrava, e não apenas através da pena dos escritores abolicionistas, mas sobretudo através da ação social das próprias vítimas e antigas vítimas da escravidão. Ficou notório por exemplo o movimento dos caifazes, uma organização que se dedicava a seqüestrar escravos das fazendas para depois conduzi-los a quilombos e, mais além, a regiões brasileiras onde já não houvesse mais escravidão (o Ceará, por exemplo, decreta o fim da escravidão em seu território em 1884, quatro anos antes da Lei Áurea). Movimentos como o dos caifazes, bem como outros, por vezes articulavam escravos e ex-escravos a uma ala mais radical do movimento abolicionista que nem sempre era a que aparecia nos jornais ou nas câmaras provinciais. Quilombos como o do Jabaquara, que se inscreviam neste mesmo circuito de alianças que se dava entre os movimentos escravos e os clubes abolicionistas mais radicais, permitem inclusive que alguns historiadores identifiquem a emergência de um novo tipo de quilombo, o "quilombo abolicionista", por oposição ao já tradicional "quilombo-rompimento" que até então fora meramente caracterizado como produto da fuga de escravos ainda sem uma articulação política maior ${ }^{24}$. Com tudo isto, estava montado o palco para a atuação de um veemente discurso abolicionista, que não excluía todavia uma ala conciliadora, e que se ocuparia de enfatizar a partir dos anos 1870 a humanidade do escravo e as injustiças sociais contra ela perpetradas.

Reempreender o deslocamento discursivo que conduz a questão escrava da coordenada das diferenças ao eixo enviesado das desigualdades seria precisamente a obra dos abolicionistas destas décadas particularmente efervescentes - o que, obviamente, não teria sido possível sem as já mencionadas pressões e mobilizações do próprio setor escravo no plano mais concreto da história vivida. O novo contexto para o fortalecimento do discurso

miscuidade com os escravos", e antes disto, com o romance O Bom Crioulo de Adolfo Caminha (1885), já desponta a figura do "negro pervertido" (PROENÇA FILHO, Domício. A trajetória do negro na literatura brasileira. Estudos avançados, São Paulo, v. 18, n. 50, p. 42). Para uma avaliação da trajetória da figura do negro na literatura brasileira, ver BROOKSHAW, David, Raça e cor na literatura brasileira. Porto Alegre: Mercado Aberto, 1983.

${ }^{24}$ SILVA, Eduardo. As Camélias do Leblon e a abolição da escravatura - uma investigação de História Cultural. São Paulo: Companhia das Letras, 2003, p. 11. 
abolicionista é este momento social, que se dá nas duas últimas décadas escravocratas, onde começam a se avolumar as resistências individuais e coletivas da própria escravaria - seja a partir de insubordinações, fugas, crimes, ou rebeliões - e onde o escravo, além de se expressar economicamente como um trabalhador ao mesmo tempo necessário e perigoso, passa a ser encarado pelos senhores do café como uma mercadoria ao mesmo tempo necessária e sujeita à instabilidade. Contra este pano de fundo e cada vez mais intensamente, sobretudo a partir de fins da década de 1870, vai tomando forma certo discurso abolicionista que chama atenção, com especial ênfase, para a necessidade de recolocar a questão da escravidão como pertinente ao campo das desigualdades.

Diga-se de passagem, o novo discurso anti-escravagista proposto pelos abolicionistas buscaria estabelecer de saída um forte contraste não apenas em relação ao discurso escravista dos senhores do Café, como também em relação ao discurso anti-escravagista de tipo "emancipacionista", ao estilo da Representação contra a Escravidão de José Bonifácio ou da Lei do Ventre Livre. De fato, Joaquim Nabuco, na abertura de sua obra O Abolicionismo, já chama atenção para o fato de que, por aquela época, "pela primeira vez se viu, dentro e fora do Parlamento, um grupo de homens fazer da emancipação dos escravos, não da limitação do cativeiro às gerações atuais, a sua bandeira política [...]"25. Ou seja, não se tratava mais de apenas evitar que surgissem novas gerações de escravos, como propusera a Lei do Ventre Livre, mas sim de libertar imediatamente os escravos já existentes.

Apenas como alguns dos inúmeros exemplos que irão contribuir para dar uma forma definida ao jargão abolicionista, poderemos citar os combativos artigos que José do Patrocínio, atuando na Imprensa do Rio de Janeiro, escreveu em períodos sucessivos para os jornais Gazeta de Notícias (1880-1881), Gazeta da Tarde (1882-1887), e Cidade do Rio (1887-1889). No mesmo ano em que se inicia esta série de artigos, em 1880, Joaquim Nabuco, José do Patrocínio e outros fundam no Rio de Janeiro a Sociedade Brasileira contra a Escravidão, base inicial para a formação de inúmeras agremiações similares. Ao mesmo tempo, em oposição aos clubes abolicionistas que começavam a surgir por toda a parte, os escravistas agrupam-se agora nos "clubes de lavoura", mostrando que os dois discursos - o escravista e o anti-escravista - estavam empenhados em uma verdadeira luta de práticas e representações. É este o ambiente de idéias sobre o qual se desenvolvem os artigos abolicionistas nos diversos jornais, alguns dos quais inclusive especializados na discussão anti-escravocrata, como foi o caso do jornal O Abolicionista, dirigido por Joaquim Nabuco.

${ }^{25}$ NABUCO, 2002, p. 23. 
Os artigos escritos por José do Patrocínio nesta época são inflamados libelos anti-escravistas através de cujo discurso passam a ser evocados diariamente os acontecimentos que, de acordo com as próprias palavras do jornalista, "abrem para o escravo uma nova época, em que a sua pessoa começa a aparecer através do animal, da cousa, que era" (GN, fev, 1881). Recolocar a passagem da "coisa", do "animal", para a "pessoa humana", é enfatizar a passagem da diferença para a desigualdade. Mais ainda, em alguns de seus artigos, José do Patrocínio inclusive já se refere explicitamente a "pessoas livres reduzidas à escravidão", com o que busca associar a Desigualdade Escrava não apenas a um problema de justiça social, mas também de legalidade ${ }^{26}$.

Sintoma bastante claro de que a base do discurso abolicionista é o reconhecimento da Escravidão como desigualdade, e não como diferença, é o fato de que os abolicionistas mais radicais não se limitavam a propor simplesmente a extinção imediata da escravidão, mas também preconizavam a sua articulação com outras questões relacionadas com o âmbito das desigualdades - como por exemplo a de uma reforma agrária que incluísse a distribuição de terras para os ex-escravos e a de uma reforma educacional que incluísse a construção de escolas públicas para os filhos de libertos. Portanto, suprimir a desigualdade escrava não deveria se dar como um ato isolado, mas sim acompanhado de outras medidas que visariam, concomitantemente, evitar que a desigualdade escrava logo se convertesse em desigualdade liberta (o que de fato aconteceu). É neste espírito que, em seu livro Agricultura Nacional (1874), André Rebouças já chamava atenção para o fato de que "até hoje, três annos depois da lei, nem a mínima providência [fora tomada] sobre a educação dos ingênuos e emancipados"27.

Nesta passagem, Rebouças refere-se ao caráter completamente inócuo de medidas que visassem a libertação de setores da escravaria (os sexagenários da lei de mesmo nome, ou os filhos de escravos da Lei do Ventre Livre) sem que isto viesse acompanhado de procedimentos capazes de assegurar aos escravos assim libertos as condições para assegurarem uma real liberdade e cidadania. Tratava a questão da libertação de escravos, portanto, não como um problema de pura e simples supressão das diferenças, mas sim de efetiva correção das desigualdades. Esse deslocamento de uma discussão que se dava no plano das diferenças para uma problematização relacionada ao âmbito das desigualda-

${ }^{26}$ Assim pode-se ler em uma matéria de José do Patrocínio para o jornal Gazeta de Notícias, em 1880: "Supondo que metade deste número é tirado dos importados depois do tráfico, temos que o número das pessoas livres reduzidas à escravidão é no Brasil nada menos de 700.000" (PATROCíNIO, Gazeta de Notícias, set. de 1880).

${ }^{27}$ REBOUÇAS, André Pinto. A Agricultura Nacional. Estudos Econômicos. Propaganda Abolicionista e Democrática. Recife: Fundação Joaquim Nabuco Editora Massangana, 1988, p. 190. 
des mostra-se fundamental na argumentação de diversos abolicionistas radicais, e entre eles André Rebouças nos oferece o corpus textual mais bem acabado. Suas preocupações, de fato, voltavam-se para muito além da mera emancipação jurídica do escravo, tocando em questões como a Educação, a Participação Política, e sobretudo o Direito à Terra. Data de 1883 a sua obra mais explícita sobre a necessidade de vincular liberdade e acesso à terra, com a importância adicional de que agora a discussão era trazida diretamente para a pregação de um abolicionismo radical que ficou registrada neste panfleto intitulado Abolição imediata e sem indenização (1883).

Na argumentação de André Rebouças, Escravidão e Monopólio da Terra - dois problemas tratados ao nível das desigualdades - aparecem intimamente relacionados, de modo que não é possível suprimir eficazmente a Escravatura sem suprimir concomitantemente a Grande Propriedade, que naturalmente vinha acoplada à correspondente concentração de poderes sociais e políticos nas mãos de uma elite agrária que podia oprimir efetivamente não apenas a escravaria como também a população livre de poucos recursos, uma vez que esta ficava obrigada a orbitar em um circuito de dependências em relação aos grandes senhores de terras ${ }^{28}$.

Percebe-se aqui que a própria Abolição Radical - sem qualquer indenização aos proprietários de escravos - é investida no discurso de Rebouças não apenas de seu evidente valor humano como também de um adicional valor como instrumento de transformação social imediato, capaz de abalar de um só golpe o poder econômico dos grandes proprietários e, conseqüentemente, abrir caminho para a Reforma Agrária. Desta maneira, a luta para abolir a Desigualdade Escrava e a luta para suprimir a Desigualdade Latifundiária aparecem como gêmeas siamesas inextrincavelmente ligadas. O grande proprietário de terras, o inimigo maior, é aqui visto simultaneamente como o principal beneficiário do sistema escravocrata e como o grande elemento de entrave à modernização social, jurídica e tecnológica do país ${ }^{29}$. Com relação a uma proposta efetiva e concreta para afrontar e constranger cada vez mais a grande propriedade, para além do impacto inicial produ-

${ }^{28}$ Sobre a articulação entre abolicionismo e a necessidade de reencaminhar a questão da terra, há algumas propostas no período. Cinco anos antes do panfleto escrito por Rebouças, encontraremos por exemplo a proposta de Henrique Pedro Carlos de Beaurepaire-Rohan, que em um livro publicado em 1878 já discorria sobre $O$ futuro da grande lavoura e da grande propriedade, prevendo-se a transformação destas em colméias agrícolas. (in MACIEL COSTA, op. cit., p. 175).

${ }^{29}$ O grande proprietário de terras, conforme a argumentação de Rebouças, estende seu poderio nefasto nestas três direções. De um lado submete socialmente escravos e dependentes livres através da violência escravocrata e do sistema de trabalho e favorecimentos. De outro lado, desvirtua e controla a justiça no âmbito dos seus domínios senhoriais. E, por fim, obstaculiza a inovação tecnológica no âmbito da agricultura, aspecto em relação ao qual Rebouças se preocupava particularmente. 
zido pela própria Abolição, a sugestão apontada por Rebouças era a instituição de um imposto territorial ${ }^{30}$.

Da mesma forma que outras publicações mais propriamente abolicionistas, setores diversos da intelectualidade e dos meios políticos também começam a aderir ao discurso da Escravidão como Desigualdade, sendo este o caso dos positivistas que se agrupavam em torno de Miguel Lemos, e que concebiam o escravismo como uma forma extremamente atrasada de organizar o trabalho e, dentro desta, os grupos humanos sujeitos à escravidão ${ }^{31}$. O discurso da Escravidão da Diferença, enfim, vai sendo cada vez mais confrontado a um discurso da Desigualdade da Escravidão, e isto em setores que iam dos mais radicais aos conservadores. Mas isto naturalmente se deu através de uma verdadeira luta de representações, porque também havia discursos favoráveis à noção de Diferença Escrava. Respingos finais desta luta de representações, aliás, aparecem já à beira da promulgação da Lei Áurea nos registros da Discussão na Câmara dos Deputados e no Senado - desde a apresentação da proposta do Governo até a sua sanção, publicada em 1889. Ali, abolicionistas históricos como Joaquim Nabuco e representantes dos redutos escravistas, como André Figueiras, trocam entre si farpas discursivas que bem retratam a encenação política tão típica desta época.

Por outro lado, é muito interessante constatar que a percepção ou o reconhecimento da Escravidão como desigualdade já começava a contaminar os próprios escravistas. Assim,

30 Para uma abordagem mais detalhada da interação entre as propostas de Abolição da Escravatura e de Reforma Agrária, tomando como base textos de Rebouças e de Joaquim Nabuco, ver a análise do brasilianista Richard Graham (1979), para quem o programa de associação entre abolição e "democracia rural" (expressão que circulava nos próprios jornais da época) não seria reivindicação exclusiva dos abolicionistas radicais (GRAHAM, Richard. Escravidão, Reforma e Imperialismo. São Paulo: Perspectiva, 1979).

31 Dentro do circuito positivista de propostas para o escravismo, é peculiarmente interessante o modelo de Brandão Júnior, uma proposta no estilo emancipacionista mas que propunha a transição do 'sistema escravista' em um 'sistema de servidão' ao estilo feudal. Conforme seu opúsculo intitulado "Aplicando à realidade brasileira a lei geral da evolução humana" (1865), tratava-se de transformar os escravos em servos, o que novamente nos conduz a uma avaliação do escravismo como sistema de desigualdades. Um sistema de desigualdades, enfim, pode ser, sem maiores dificuldades, substituído por outro. Miguel Lemos, que escreveria no período de maior acirramento do debate abolicionista (anos 1880) rejeita esta proposta por considerá-la inviável, sobretudo nos aspectos relativos à fiscalização que se tornaria necessária para evitar que a servidão não se transformasse em mais do que uma mera fachada para a escravidão. Enquanto isso, Pereira Barreto advogava em artigos publicados no jornal A Província de São Paulo um modelo emancipacionista baseado na convicção de que para eliminar definitivamente o modelo escravista seria necessário empreender uma "preparação psicológica e econômica da sociedade", uma vez que "qualquer reforma antes de se tornar um fato precisa ser por muito tempo uma idéia assimilada, uma parte integrante da circulação mental da época (MACIEL DA COSTA, 1980: 431). Sobre isto, ver INNOCÊNCIO, Isabela Torres de Castro. Liberdade e acesso à terra: Fazenda de Cantagalo - Paraíba do Sul (1822-1932), Vassouras: USS, 2002, p. 56. 
mesmo o escritor cearense José de Alencar (1829-1877) - escravista assumido - chegou a utilizar um argumento que não deixa de denunciar a percepção da escravidão como desigualdade (e não como diferença), ao sustentar que se justificava a manutenção da escravidão porque os operários europeus viviam em condições piores do que os escravos (!). Comparar o trabalho escravo ao trabalho assalariado, de um modo ou de outro, é reintroduzi-lo francamente no mundo das desigualdades.

Outro ponto importante a se destacar é que, na medida em que se desentrelaçavam as noções de negro e de Escravo - esta última a ser desconstruída pelo processo da abolição - nem por isso houve necessário recuo do discurso que opunha desniveladamente a Diferença Negra à Diferença Branca. É impressionante como o discurso científico da época, e isto perdura até as três primeiras décadas do século $X X$, amparava-se ainda na idéia de inferioridade da "raça negra". Ainda no ano que precede a abolição, Oliveira Martins assim registrava as suas idéias acerca de uma hierarquia natural das raças humanas, e, portanto, de acordo com o nosso quadro conceitual, de uma hierarquia das diferenças.

“Há decerto, e abundam os documentos que nos mostram no negro um tipo antropologicamente inferior, não raro próximo do antropóide, e bem pouco digno do nome de homem." ${ }^{\prime 2}$

O discurso de uma Diferença Negra que estaria assinalada por uma pretensa inferioridade do negro, em contraposição à idéia de que o que ocorria na verdade era uma inferiorização do negro ocasionada pela Desigualdade Escrava, manteria seus partidários para além da abolição, da mesma maneira que tinha suas raízes fincadas nas décadas precedentes. As décadas que precedem e as que sucedem a Abolição constituem de fato o palco de uma acirrada luta de representações, e é bastante citar a polêmica que se estabelecera, já no alvorecer dos anos 1880, em torno de idéias racistas expressas pelo médico francês Louis Couty em seu livro A Escravidão no Brasil (1880), gerando artigos de repúdio nos jornais abolicionistas da época.

O entrelaçamento histórico entre a Diferença Negra (também uma construção) e a Desigualdade escrava - esta por vezes vertida em Diferença Escrava - foi tão incompreendido ou dissimulado por alguns dos intelectuais do período imediatamente anterior e posterior ao desmantelamento do sistema escravocrata, que aparecem à míngua estas análises que buscam enxergar uma 'inferioridade da diferença' com base em argumentações que na verdade estariam é levando em consideração a 'inferiorização escrava'. Ao

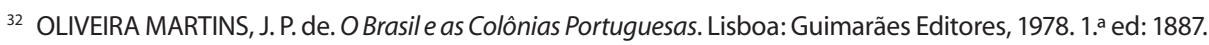


contrário, a contribuição de alguns dos maiores intelectuais abolicionistas para o problema foi perceber precisamente este entrelaçamento circunstancial entre a Diferença Negra e a Desigualdade Escrava, de modo a desmantelar conjuntamente com o sistema escravocrata também um discurso pseudo-cientificista que confundia inferioridade negra com inferiorização escrava. Por isso Joaquim Nabuco - abolicionista filho da elite pernambucana - procurava em seu livro O Abolicionismo esclarecer que não podia de maneira nenhuma ser colocado como um problema para a formação da população brasileira a "raça negra", mas sim esta "raça negra reduzida ao cativeiro". O problema então, por outras palavras, fora esse entrelaçamento que - entretecendo práticas aviltantes as mais diversas - forjara-se em condições degradantes, vinculando em um entremeado de diferenças e desigualdades as noções de "negro", "africano" e "escravo".

\section{Joaquim Nabuco: fragmentos de um discurso abolicionista}

Tal como se disse, a contribuição crítica para as discussões sobre o fim da sociedade escravocrata foram inúmeras nas duas décadas abolicionistas, e ainda mais intensa nos anos 1880. Diversas propostas, artigos e discursos surgem neste período - seja a partir da concepção abolicionista, da concepção emancipacionista, ou mesmo do ponto de vista pró-escravista. A densidade de discussões sobre a questão escrava nestas duas décadas é incomparável em relação ao relativo vazio discursivo que rendera apenas uma dezena de obras significativas nas cinco décadas anteriores (1820-1870). Diante da impraticabilidade de analisar, nos limites deste ensaio, um maior número de contribuições abolicionistas e emancipacionistas, concentrar-nos-emos em um texto que se tornou um verdadeiro marco abolicionista. De fato, a contribuição analítica mais fina que pôde emergir do discurso abolicionista foi, assim pensamos, a de Joaquim Nabuco. Aqui saímos do incisivo estilo panfletário de José do Patrocínio para entrar no texto cuidadoso e cientificamente trabalhado de Joaquim Nabuco, que constrói com a sua obra O Abolicionismo um dos primeiros grandes textos das Ciências Sociais brasileiras.

Um certo trecho deste que é o segundo livro de Joaquim Nabuco sobre a questão escravocrata $^{33}$, entre outras passagens igualmente remarcáveis, mostra-se particularmente significativo como sintoma de uma concepção abolicionista que percebe o tradicional tratamento da Escravidão como Diferença e decide enfrentá-lo com o projeto de trazer a

${ }^{33}$ Em 1869, aos vinte anos de idade, Joaquim Nabuco havia escrito já um outro livro, intitulado $A$ Escravidão, que permaneceu inédito até 1989. Neste mesmo ano de 1869, um ano antes de se formar em Ciências Sociais e Jurídicas, Nabuco já havia causado algum escândalo na elite cearense por ter se proposto a defender, como advogado, um escravo que assassinara o seu senhor. É também deste ano o opúsculo O povo e o trono. 
discussão para o âmbito das Desigualdades. O trecho resume de maneira esplêndida este deslocamento discursivo que, rejeitando-a, vai da 'Diferença Escrava' para a 'Desigualdade Escrava', daí a uma 'Desigualdade Liberta', e por fim se realiza na promessa e na proposta de minimizar as desigualdades várias de modo a constituir para o ex-escravo libertado um mundo pleno de cidadania e verdadeira liberdade:

“Depois que os últimos escravos tiverem sido arrancados ao Poder sinistro que representa para os escravos a maldição da cor, será ainda preciso desbastar, por meio de uma educação viril e séria, a lenta estratificação de trezentos anos de cativeiro, isto é, de despotismo, superstição e ignorância. O processo natural pelo qual a Escravidão fossilizou nos seus moldes a exuberante vitalidade do nosso povo durou todo o período de crescimento, e enquanto a Nação não tiver consciência de que lhe é indispensável adaptar à liberdade cada um dos aparelhos do seu organismo de que a escravidão se apropriou, a obra desta irá por diante, mesmo quando não haja mais escravos." ${ }^{134}$

Dificilmente poderia haver imagem mais adequada para a Diferença Escrava - a diferença que se constrói sobre esta cor negra que, vimos atrás, é ela mesma uma construção social - do que esse "Poder Sinistro" que cria para o escravo a representação da "maldição da cor" (lembremos da maldição que o texto bíblico faz se abater sobre Canaã, e que os cristãos europeus procuram traduzir em termos de uma maldição sacralizada que se estabelece sobre o homem negro). Arrancar o escravo, cada escravo, a este Poder Sinistro, não é nada mais do que desconstruir a idéia de uma Escravidão da Cor, de uma diferença escrava que se baseia tão somente na cor da pele e na origem africana. Mas há mais: é preciso em seguida enfrentar o problema da Desigualdade Escrava - esta que se ocultava sob a Diferença Escrava como uma segunda natureza e que agora se vê exposta, produto de "trezentos anos de cativeiro", mais do que isto, de trezentos anos de um sistema que se imiscui em todos os aspectos da vida social brasileira e que afeta na verdade todas as classes.

A idéia de que "a Escravidão fossilizou nos seus moldes" a vitalidade do povo brasileiro, criando categorias que agora precisam ser desconstruídas - a do senhor e a do escravo - é novamente oportuna. A consciência de que a liberdade deverá ser reconquistada gradualmente, "adaptando à liberdade cada um dos aparelhos do organismo social", é apontada como a principal virtude de que deverá se revestir a Nação na sua tarefa de estabelecer o reino da Igualdade. Caso contrário, acrescenta o autor de maneira particularmente visionária, a obra da Escravidão seguirá adiante, "mesmo quando não haja mais escravos".

${ }^{34}$ NABUCO, 2002, p. 25. 
Essa passagem final do trecho selecionado é particularmente interessante. Para existir, ou para se fazer presente através dos seus desdobramentos e efeitos mais funestos, a Escravidão não precisa necessariamente de escravos. Os seus efeitos, na verdade os seus tricentenários moldes, poderiam se estender não apenas sobre os libertos ou sobre os afro-descendentes (o que, de resto, é uma das implicações imediatas), mas também sobre a sociedade como um todo. Esta passagem, tão enigmática quanto dotada de uma beleza lógica, pode ser mais facilmente compreendida a partir do aspecto que será discutido a seguir, central na conceituação sobre Escravidão elaborada por Joaquim Nabuco.

O principal mérito de Joaquim Nabuco em O Abolicionismo é ir além da simples análise da Escravidão como um simples processo de tirania social, onde o homem devora o homem como força de trabalho submetida compulsoriamente com a perda de si mesmo ao se tornar a propriedade de um outro. Para além disto, vê-se desde o primeiro capítulo da obra, trata-se de examinar a Escravidão como Sistema. A Escravidão, complexo sistema instituidor de desigualdades que abrange para muito além de seus pólos humanos mais visíveis - o 'senhor' e o 'escravo' - precisa ser decifrada como tal, como sistema que articula poderes instituídos e redes de clientela, uma forma de propriedade e um regime de trabalho, o apoio em um padrão de religiosidade e uma interpenetração entre âmbitos políticos os mais diversos, que vão do Parlamento à Coroa e ao Estado em sentido mais amplo. Tudo, na Escravidão, se articula como partes de um sistema cuidadosamente construído por três séculos de "despotismo, superstição e ignorância":

"Assim como a palavra Abolicionismo, a palavra Escravidão é tomada neste livro em sentido lato. Esta não significa somente a relação do escravo para com o senhor; significa muito mais: a soma do poderio, influência capital, e clientela dos senhores todos; o feudalismo estabelecido no interior; a dependência em que o comércio, a religião, a pobreza, a indústria, o Parlamento, a Coroa, o Estado, enfim, se acham perante o poder agregado da minoria aristocrática, em cujas senzalas centenas de milhares de entes humanos vivem embrutecidos e moralmente mutilados pelo próprio regímen a que estão sujeitos; e, por último, o espírito, o espírito vital que anima a instituição toda, sobretudo no momento em que ela entra a recear pela posse imemorial em que se acha investida, espírito que há sido em toda a história dos países escravos a causa da sua ruína." ${ }^{35}$

A Escravidão transparece aqui como um sistema que dá funcionamento à realidade social, política e econômica, interna a um país, mas que também afeta o mundo externo,

35 NABUCO, 2000, p. 26. 
os países que são constituídos em fontes de escravos. Diga-se de passagem, os "países escravos" que o "espírito da Escravidão" arruína, não são apenas na argumentação proposta por Nabuco os países que fornecem escravos - como os vários reinos africanos mas também os próprios países que os recebem, e que desta forma deixam a escravidão se entranhar na sua sociedade, criando as figuras simultaneamente grotescas do "senhor" e do "escravo" e, sobretudo, um sistema que termina por aprisionar a própria nação.

A Igreja, veremos em outra passagem desta que é a obra prima de Joaquim Nabuco, ajusta-se a este sistema com pouco pudor, de modo que o escritor cearense pode afirmar enfaticamente que "a Igreja Católica, apesar do seu imenso poderio em um país ainda em grande parte fanatizado por ela, nunca elevou no Brasil a voz em favor da emancipação"36. Insinua-se aqui que a Igreja foi aqui apropriada como parte do sistema, como algo que lhe dá suporte através da "superstição" e da "ignorância" que terminam por se verem sacralizadas por uma Igreja omissa e ideologicamente conivente.

De passagem, é preciso salientar que a imagem de que "a Escravidão pode seguir adiante mesmo além dos escravos" refere-se também, em uma das suas dimensões de sentido, ao diálogo de confronto que o Abolicionismo estabelece com o Emancipacionismo, esta outra modalidade de anti-escravagismo que vinha enfrentando a questão escrava com seus próprios métodos e concepções. É neste contexto, inclusive de crítica à Lei do Ventre Livre (1871), principal realização do Emancipacionismo, que a imagem empregada por Joaquim Nabuco se fortalece. Se ela traz este sentido mais sutil de que a Escravidão deve ser enfrentada na totalidade de aspectos que nela interagem como peças fundamentais de um sistema, a mesma imagem também carregava um sentido mais prático que visava confrontar diretamente os efeitos da Lei do Ventre Livre - esta lei emancipacionista que até à idade de oito anos colocava sob a tutela do senhor o "ingênuo" (o filho de escravo que nascia liberto), e que, depois desta idade, abria a possibilidade de que o ingênuo permanecesse como dependente do senhor até os 21 anos (a alternativa era o senhor receber uma quantia de $\$ 600,00$ para desligar mais cedo o liberto). Conforme argumenta Nabuco, a depender da Lei do Ventre Livre a escravidão ainda iria ser diretamente prolongada no país por mais cinqüenta anos:

“Pela lei de 28 de setembro de 1871, a escravidão tem por limite a vida do escravo nascido na véspera da lei. Mas essas águas mesmas não estão ainda estagnadas, porque a fonte do nascimento não foi cortada, e todos os anos as mulheres escravas dão milhares de escravos por vinte e um anos aos seus senhores. Por uma ficção de direito, eles nascem livres, mas, de

${ }^{36}$ NABUCO, p. 2002, p. 31. 
fato, valem por lei aos oito anos de idade 600\$, cada um. A escrava nascida a 27 de setembro de 1871 pode ser mãe em 1911 de um desses ingênuos, que assim ficaria em cativeiro provisório até 1932. Essa é a lei, e o período de escravidão que ela ainda permite."137

Essa espera legalizada, mesmo que abreviada por eventual generosidade dos antigos senhores - e Nabuco propõe um mínimo de vinte anos para este cálculo - seria fatal em uma nação na qual a Escravidão se convertera já em sistema ("vinte anos mais de escravidão, é a morte do país", dirá mais adiante). Ironicamente, subentende-se a partir da argumentação de Nabuco, é precisamente porque no Brasil a Escravidão se entranhara sob a égide da Desigualdade Escrava (mesmo nos períodos em que ela fora a segunda natureza de uma Diferença Escrava), que a questão da necessidade de um encaminhamento adequado ao processo abolicionista mostrava-se mais delicada do que nos Estados Unidos, onde a escravidão fora sempre tratada sob a égide de uma Diferença Escrava, que desde o princípio conservara bem fortemente a imiscibilidade das duas raças. Obviamente que Nabuco não utiliza este sistema conceitual e não fala em 'diferenças' e 'desigualdades escravas', mas a questão está implícita, inclusive quando ele compara os sistemas escravocratas antigos, o brasileiro e o americano:

“Atenas, Roma, a Virgínia, por exemplo, foram, tomando uma comparação química, simples misturas nas quais os diversos elementos guardavam as suas propriedades particulares; o Brasil, porém, é um composto do qual a escravidão representa a afinidade causal. O problema que nós queremos resolver é o de fazer desse composto de senhor e escravo um cidadão. O dos Estados Unidos foi muito diverso, porque essas duas espécies não se misturaram. Entre nós a escravidão não exerceu toda a sua influência apenas abaixo da linha romana ad libertas: exerceu-a, também, dentro e acima da espera da civitas; nivelou-a, exceção feita aos escravos, que vivem sempre nos subterrâneos sociais, todas as classes; mas nivelou-as degradando-as. Daí a dificuldade de analisar-lhe a influência, de descobrir um ponto qualquer, ou na índole do povo, ou na face do país, ou mesmo nas alturas mais distantes das emanações das senzalas, sobre que, de alguma forma, aquela afinidade não atuasse, e que não deva ser incluída na síntese nacional da escravidão." ${ }^{38}$

Voltamos então, a esta que parece ser a contribuição mais original de Joaquim Nabuco com a análise empreendida em O Abolicionismo: a de examinar o Escravismo como sistema integrado cujos efeitos interpenetram todas as classes sociais não-escravas e que envolve os

\footnotetext{
37 NABUCO, 2000, p. 131.

38 NABUCO, 2000, p. 35.
} 
diversos aspectos da vida social, política e imaginária da sociedade que o acolhe e dele faz a sua principal sustentação. Nesta proposta de análise, Joaquim Nabuco talvez se antecipa em alguns pontos às grandes abordagens do século XX, que se empenhariam em compreender o escravismo como sistema, como complexo de aspectos diversos que mutuamente se interferem ${ }^{39}$. A Escravidão, compreendida como sistema gerador e mantenedor de desigualdades, estaria constituída não apenas de uma base material, social e política que lhe dariam conteúdo e forma, mas também de uma dimensão imaginária (a expressão não é utilizada por Joaquim Nabuco), de um "espírito" que a ela corresponderia. Aqui, em um ponto nodal onde se encontram a análise estrutural e a avaliação conjuntural elaboradas por Nabuco, compreende-se a preocupação do autor expressa no penúltimo capítulo de sua obra com relação aos "perigos da demora". Protelar a abolição radical e definitiva da Escravidão por mais vinte anos que fosse, equivaleria a, neste período, permitir que novas gerações continuassem a ser educadas no Imaginário da escravidão, na escola da diferença ou da desigualdade escrava; ou, para utilizar as próprias palavras de Nabuco, condenar "a atual mocidade" a "viver com a Escravidão", "a servi-la durante a melhor parte de sua vida, a manter um exército, e uma magistratura para torná-la obrigatória, e, pior talvez do que isso, a ver as crianças, que hão de tomar os seus lugares dentro de vinte anos, educadas na mesma escola que ela [a escravidão]"40.

Essa passagem é particularmente interessante, porque através dela compreendemos os dois sentidos da sentença empregada por Joaquim Nabuco no início de sua obra, segundo a qual "a Escravidão poderia prosseguir até mesmo para além dos próprios escravos". Há uma fina percepção da psicologia social nesta análise do autor de O Abolicionismo. Por um lado, o complexo sistema da diferença e da desigualdade escrava produz um modo de pensar, uma dimensão imaginária - um "espírito" - que apresenta uma sobrevida capaz de seguir mesmo para além da destruição das bases materiais mais imediatas deste sistema, dadas estas por um modo específico de exploração da mão-de-obra escrava e pela sua justificação jurídica. Extintos o trabalho escravo e a noção da propriedade escrava, não se extinguem imediatamente os padrões de sociabilidade e o imaginário escravos que um dia lhe corresponderam, agora tendentes a se refugiar na discriminação social e no preconceito, ou em outras maneiras de pensar consoante as categorias do sistema escravista.

${ }^{39}$ O Escravismo Brasileiro, aqui, emerge com uma especificidade que lhe é toda própria. Vale a pena examinar, ainda a propósito, a seguinte passagem: "Não se trata, somente, no caso da escravidão no Brasil, de uma instituição que ponha fora da sociedade um imenso número de indivíduos, como na Grécia ou na Itália antiga, e lhes dê por função social trabalhar para os cidadãos; trata-se de uma sociedade não só baseada, como era a civilização antiga, sobre a escravidão, e permeada em todas as classes por ela, mas também constituída, na sua maior parte, de secreções daquele vasto aparelho" (NABUCO, 2002, p. 133).

${ }^{40}$ NABUCO, 2002, p. 133. 
Por outro lado, o indivíduo livre que até 1932 convivesse com o último "ingênuo" ainda submetido a um padrão de dependência muito próximo ao das relações escravistas, ou com o último dos sexagenários ainda formalmente escravo ${ }^{41}$, também este arrastaria para a sua vida um padrão deteriorado de conceber as relações humanas. Tal é a hipótese sustentada por Joaquim Nabuco.

A caracterização da Escravidão como sistema que se entranha no Brasil redefinindo-lhe a economia, a política, a sociedade - de um modo como não se entranhou nos países europeus, por exemplo - permite que Joaquim Nabuco também identifique um sentido especial no Abolicionismo brasileiro. Este emerge - para dar conta da tarefa histórica que Ihe é imposta diante de um inimigo que já se entranhou na sociedade e se constituiu em sistema - sobretudo em sua dimensão política, permitindo-se contrastá-lo, como assinala Nabuco, com o Abolicionismo inglês, "movimento religioso e filantrópico determinado por sentimentos que nada tinham de político, senão no sentido de que se pode chamar de política à moral social do Evangelho" ${ }^{1 / 42}$. De fato, a um movimento anti-escravagista inglês que vai encontrar algumas de suas principais lideranças na seita religiosa dos quackers, ou em humanitários como Thomas Clarkson, pode ser francamente contraposto ao movimento abolicionista liderado por homens como Joaquim Nabuco, André Rebouças e José do Patrocínio, e que nas suas ações mais radicais vai atuar sincronicamente com movimentos surgidos da própria escravaria insurrecta ou dos libertos.

A questão das diferenças de cor, por fim, permite que Joaquim Nabuco contraste a sociedade que emerge do fim do escravagismo americano com esta outra sociedade que está prestes a emergir da derrocada do escravagismo brasileiro, fundada "nessa boa inteligência em que vivem os elementos de origem diferente, da nossa nacionalidade" vindo a consistir em "um interesse público de primeira ordem para nós ${ }^{\prime \prime 43}$. Aqui, a sociabilidade

41 A Lei n. 3270 - Lei Saraiva-Cotegipe ou Lei dos Sexagenários (1885) - estimava a libertação dos escravos com idade igual ou superior a 60 anos, mas ainda previa um pequeno período adicional de dependência em relação ao antigo senhor. O 'artigo 3. §10' estipula que "são libertos os escravos de 60 anos de idade, completos antes e depois da data em que entrar em execução esta lei, ficando, porém, obrigados a título de indenização pela sua alforria, a prestar serviços a seus ex-senhores pelo espaço de três anos". O 'artigo 4. $§ 3, c^{\prime}$ estipula ainda uma maior margem de dependência beneficiando os senhores que se interessassem em substituir o trabalho escravo pelo trabalho livre, prevendo neste caso a "usufruição dos serviços dos libertos por tempo de cinco anos". Com isto, o último escravo, às vésperas da promulgação da Lei do Ventre Livre, em 1871, poderia estar entrando em sua vida independente entre 1933 e 1935 . Com relação aos últimos ingênuos, Nabuco nos fornece o seguinte cálculo aproximado: "A escrava nascida a 27 de setembro de 1871 pode ser mãe em 1911 de um desses ingênuos, que assim ficaria em cativeiro provisório até 1932. Essa é a lei, e o período de escravidão que ela ainda permite" (NABUCO, 2002, p. 131).

42 NABUCO, 2002, p. 32.

43 NABUCO, 2002, p. 34. A perspectiva de Nabuco sobre a convivência entre as duas "raças" parece antecipar a postura de Freyre, décadas depois. É Nabuco quem nos diz: "A escravidão, por felicidade nossa, 
mais fácil entre as "diferenças de cor" e a 'inteligência da mestiçagem' recebem mais uma vez um elogio. O Brasil mostra-se aqui um país mestiço, e não se postula qualquer projeto de excluir as diferenças ou de reenviá-las para os seus portos de origem.

A visão da Escravidão como Sistema, a consciência da mestiçagem nacional e um espírito francamente conciliatório, que tenta re-educar o próprio senhor de modo a que ele veja que o Escravismo é também uma corrente para ele mesmo e obstáculo para o progresso do país, terminam por tingir o abolicionismo de Joaquim Nabuco de uma tonalidade menos radical e agressiva do que a de José do Patrocínio, por exemplo, com seus inflamados artigos na Imprensa carioca. Uma meta inflexível de interromper radicalmente a escravidão de uma só vez, mas buscando reajustes conciliatórios na sociedade liberta, tal parece ser a proposta do Nabuco abolicionista:

“Por isso também os abolicionistas, que querem conciliar todas as classes, e não indispor umas contra outras, que não pedem a emancipação no interesse tão somente do escravo, mas do próprio senhor, e da sociedade toda; não podem querer instilar no coração do oprimido um ódio que ele não sente, e muito menos fazer apelo a paixões que não servem para fermento de uma causa, que não se resume na reabilitação da raça negra, mas que é equivalente, como vimos, à reconstituição completa do país." ${ }^{\text {"4 }}$

As idéias, encaminhadas logo a seguir, de que "a propaganda abolicionista não se dirige, com efeito, aos escravos", e de que o partido abolicionista deve se recusar "incitar à insurreição ou ao crime ${ }^{\prime \prime 4}$ parecem situar Joaquim Nabuco - apesar de sua atuação incisiva e indispensável até a assinatura da Lei Áurea - em uma ala relativamente mais moderada do abolicionismo se o compararmos com aqueles setores mais radicais que chegaram inclusive a tramar ações sociais com grupos de escravos fugidos ou de ex-libertos, entretecendo estratégias mais agressivas que incorporavam nos seus programas de ação tanto "quilombos abolicionistas" como sociedades libertadoras como a dos caifazes. Também é um abolicionismo moderado este que se desenha a partir da pena de Nabuco quando o comparamos com jornalistas mais inflamados que desafiavam mais abertamente os senhores, não apenas recusando-se a discutir qualquer indenização a lhes ser paga pela súbita supressão

não azedou nunca a alma do escravo contra o senhor - falando coletivamente - nem criou entre as duas raças o ódio recíproco que existe naturalmente entre opressores e oprimidos. Por este motivo o contato entre elas sempre foi isento de asperezas, fora da escravidão, e o homem de cor achou todas as avenidas abertas diante de si" (NABUCO, 2002, pp. 33-34).

${ }^{44}$ NABUCO, 2000, p. 35.

45 NABUCO, 2000, p. 35. 
da propriedade como, em certos casos, até chegando a exigir dos próprios senhores indenizações para os negros em nome de escravizações indevidas durante anos ${ }^{46}$.

Assim, a oposição de Joaquim Nabuco a uma postura que instigue a insurreição escrava o situa claramente em algum ponto intermédio entre o Emancipacionismo mais moderado que fora o de José Bonifácio e o Abolicionismo mais radical que se destila na rede de apoio ao quilombo do Jabaquara ou nos artigos mais inflamados de José do Patrocínio. Em uma passagem que parece remontar ao medo branco diante das hordas negras do Haiti lideradas por Toussaint L'Ouverture, Nabuco situa o seu lugar exato entre os ídolos e contra-ídolos da sua modalidade específica de abolicionismo:

"este [o caos gerado por uma insurreição generalizada que partisse dos escravos] seria o sinal de morte do abolicionismo de Wilberforce, Lamartine e Garrison, que é o nosso, e do começo do abolicionismo de Catilina ou de Spartacus, ou de John Brown."${ }^{147}$

A solução parlamentar, como lócus privilegiado para resolver a questão escrava, afirma-se com bastante clareza na parte mais política e programática de $O$ Abolicionismo. Rejeitando simultaneamente o paternalismo Imperial e a insurreição popular, o Parlamento - depois de resolvidas as disputas internas e este - parece se afirmar em Nabuco como uma vanguarda política necessária para representar simultaneamente os interesses dos escravos e dos senhores mais conscientes. Um poder, enfim, que se encontra suspenso entre os gestos do paternalismo majestático e da intolerância revolucionária:

“[...] Não é igualmente provável que semelhante reforma seja feita por um decreto majestático da Coroa, como foi na Rússia, nem por um ato de inteira iniciativa e responsabilidade do governo central, como foi, nos Estados Unidos, a proclamação de Lincoln. / A emancipação há de ser feita, entre nós, por uma lei que tenha os requisitos, externos e internos, de todas as outras. É, assim, no Parlamento e não em fazendas ou quilombos do interior, nem nas ruas e praças das cidades, que se há de ganhar, ou perder, a causa da liberdade."148

${ }^{46}$ PATROCÍNIO, Gazeta de Notícias, 8.3.1880. Desta maneira argumenta José do Patrocínio em um artigo para a Gazeta de Notícias de 6 de março de 1880: “O problema da escravidão está neste pé. A lei de 1831 suprimiu o tráfico e não só declarou criminosos os introdutores, como obrigados à restituição do africano os compradores. Há quarenta e nove anos e dois dias, pois, nenhum africano podia mais ser escravizado no Brasil. [...] Ora, é de lei que o salário do homem escravizado seja pago por quem o escravizou, ou quem herdou os capitais deste. / Logo, os atuais proprietários de escravos devem à sociedade em geral, ou melhor, à raça negra, quarenta e nove anos de salário.

47 NABUCO, 2002, p. 35.

${ }^{48}$ NABUCO, 2002, pp. 35-36. 
O abolicionismo de Joaquim Nabuco, de certo modo, termina por ser um pouco um negócio de brancos, para utilizar uma expressão crítica que mais tarde foi dirigida às contribuições mais moderadas do abolicionismo brasileiro. Mas é, de todo o modo, inegável a importância de sua atuação como jornalista e parlamentar. Mais importante, ainda, terá sido a parte analítica de sua obra - menos a obra de juventude intitulada A Escravidão do que a brilhante análise concretizada na maturidade sob o título de O Abolicionismo, este sim um ensaio que se introduz na literatura nacional como a primeira obra brasileira mais complexa no campo das Ciências Políticas e das Ciências Sociais, terminando por realizar com sucesso o retrato bem cuidado de um país prestes a se lançar a novas transformações. Eis, enfim, a obra-prima de Joaquim Nabuco, a mais fina consciência do abolicionismo vertida em um belo texto que buscou decifrar sistematicamente o sistema da Escravidão de modo a propor concomitantemente a sua descontrução, com vistas a favorecer o advento de uma Sociedade de cidadanias plenas.

Um panorama final se torna agora possível no que concerne à história das idéias anti-escravagistas no Brasil, já à luz da perspectiva dos deslocamentos entre as coordenadas das Diferenças e o eixo de contradições relacionado às Desigualdades. O Anti-Escravagismo no Brasil, como tivemos a oportunidade de ver, pautou-se desde o texto pioneiro de José Bonifácio em algumas posturas distintas.

A primeira postura possível - de José Bonifácio a medidas constitucionais como a Lei Eusébio de Queiroz (proibição do tráfico), a Lei do Ventre Livre e a Lei dos Sexagenários, passando ainda por alguns textos esparsos e pela famosa "Fala do Trono" pronunciada em 1866 por Dom Pedro II - seria esta que se convencionou chamar de "Emancipacionismo". Seu projeto de "morte lenta" da Escravidão, embora introduzindo algumas leituras que já examinavam o Escravismo como Desigualdade, e não como Diferença, não propôs na prática nada mais do que deixar a Diferença Escrava lentamente dissolver-se no ar, limitando o campo de ação do Escravismo primeiro no espaço-tempo (a proibição do tráfico-atlântico), depois reduzindo as gerações de homens a ele sujeitas (Lei do Ventre Livre e Lei dos Sexagenários). Mas, aparentemente impondo alguns retoques ao pólo escravo, deixara ainda intacto o pólo senhorial - uma vez que esta postura parece examinar o Escravismo como um 'gesto de desigualdade', mas não como um 'sistema de desigualdade'.

A segunda postura, o "Abolicionismo" propriamente dito, propõe efetivamente uma nova leitura do Escravismo que se estabelece sobre um deslocamento que vai da Diferença Escrava à Desigualdade Escrava. A partir daí, as leituras desdobram-se e diversificam-se. A Escravidão vista como sistema, e não como um simples gesto de escravizar - esta concepção que encontrou sua mais fina expressão na obra analítica de Joaquim Nabuco permitiria por exemplo que se atacasse a dicotomia "senhor-escravo" mais do que sim- 
plesmente libertar o escravo ou punir moral e pecuniariamente o senhor de escravos. A análise da Escravidão como concretização suprema de uma tirania estabelecida pelo homem branco europeu contra o homem negro africano - tirania de uma diferença sobre outra, gerando simultaneamente terríveis desigualdades - encontraria suas ações mais firmes seja nos artigos inflamados de um José do Patrocínio, seja na articulação insurrecta que integraria no mesmo braço de resistência os clubes abolicionistas mais exaltados, a mobilização popular, os "quilombos abolicionistas" ao estilo do Quilombo do Jabaquara, e sociedades de ação direta como a dos caifazes. Ao lado desta última via, a da ação direta, outros dois métodos insinuavam-se: a "via do Decreto Régio" e a "via Parlamentar". A história, em sua singular complexidade, conduziu os acontecimentos a se materializarem sob a influência de uma combinação dos três métodos: sob a pressão do método insurrecional da "ação direta", terminaram-se por se unir numa única via o gesto do Decreto Régio e o gesto Parlamentar. E fez-se a Lei Áurea, oficialmente extinguindo no Brasil a Diferença Escrava e a Desigualdade Escrava.

\section{Referências}

\section{Fontes}

ANDRADA E SILVA, José Bonifácio de. "Representação à Assembléia Geral Constituinte e Legislativa do Império do Brasil sobre a Escravatura" in MACIEL COSTA, João Severiano Maciel da et alii. Memórias Sobre a Escravidão. Rio de Janeiro / Brasília: Arquivo Nacional / Fundação Petrônio Portella / Ministério da Justiça, 1988.

BEAUREPAIRE-ROHAN, Pedro Carlos de. "O futuro da grande lavoura e da grande propriedade" in MACIEL DA COSTA, João Severiano et alii. Memórias Sobre a Escravidão. Rio de Janeiro / Brasília: Arquivo Nacional / Fundação Petrônio Portella / Ministério da Justiça, 1988.

MACIEL DA COSTA, João Severiano. "Memória sobre a necessidade de abolir a introdução de escravos africanos no Brasil, sobre o modo e condições com que esta abolição se deve fazer e sobre os meios de remediar a falta de braços que ela pode ocasionar (1821)" in MACIEL DA COSTA et alii. Memórias Sobre a Escravidão. Rio de Janeiro / Brasília: Arquivo Nacional / Fundação Petrônio Portella / Ministério da Justiça, 1988, pp. 9-61.

NABUCO, Joaquim. O Abolicionismo in SANTIAGO, Silviano (org.) Intérpretes do Brasil. Rio de Janeiro: Nova Aguilar, 2002. pp. 23-167.

OLIVEIRA MARTINS, J. P. de. O Brasil e as Colônias Portuguesas. Lisboa: Guimarães Editores, 1978. 1. ${ }^{\mathrm{a}}$ ed: 1887.

PATROCÍNIO, José. Artigos Abolicionistas dos jornais Gazeta de Notícias (1880-1881), Gazeta da Tarde (1882-1887), e Cidade do Rio (1887-1889). 
REBOUÇAS, André Pinto. A Agricultura Nacional. Estudos Econômicos. Propaganda Abolicionista e Democrática. Recife: Fundação Joaquim Nabuco Editora Massangana, 1988.

SILVA, José Eloy Pessoa da. "Memória sobre a escravatura e projeto de colonização dos europeus e pretos da África no Império do Brasil (1826)" in MACIEL DA COSTA, op. cit., p. 416.

\section{Bibliografia}

BARROS, José, Igualdade, Desigualdade e Diferença - rediscutindo três noções. Análise Social (Revista do Instituto de Ciências Sociais da Universidade de Lisboa), n. 175, volume 11, verão de 2005, pp. 345-366.

BROOKSHAW, David, Raça e cor na literatura brasileira. Porto Alegre: Mercado Aberto, 1983.

CASTRO, Hebe Maria Mattos. Das cores do silêncio. Os Significados da Liberdade no Sudeste Escravista - Brasil Século XIX. Rio de Janeiro: Arquivo Nacional, 1995.

CONRAD, Robert. Os últimos anos da escravatura no Brasil - 1850-1888. Rio de Janeiro: Civilização Brasileira, 1975.

FRAGOSO, João. "O Império Escravista e a República dos Plantadores" in LINHARES, Maria Yedda (org.) História Geral do Brasil. Rio de Janeiro: Campus, 2000.

INNOCÊNCIO, Isabela Torres de Castro. Liberdade e acesso à terra: Fazenda de Cantagalo Paraíba do Sul (1822-1932), Vassouras: USS, 2002.

GRAHAM, Richard. Escravidão, Reforma e Imperialismo. São Paulo: Perspectiva, 1979.

PROENÇA FILHO, Domício. A trajetória do negro na literatura brasileira. Estudos. avançados, São Paulo, v. 18, n. 50.

SILVA, Eduardo. As Camélias do Leblon e a abolição da escravatura - uma investigação de História Cultural. São Paulo: Companhia das Letras, 2003. 